Zofia Małkowicz-Daszkowska (iD) https://orcid.org/0000-0002-5921-4578

\title{
Instytucjonalne rewizje i (nie)prawdopodobne scenariusze. Polski teatr „autodiagnostyczny”.
}

\author{
Abstract \\ Institutional Revisions and (Un)likely Scenarios. The Polish "Self- \\ -diagnostic" Theatre
}

The paper discusses the phenomenon of theatre performances as well as the curator practices focussed on the organisational/production/administrative dimension of a theatre which is reserved for theatre employees or experts with specialist knowledge and thus usually unavailable to a wide audience. We will treat the selected practices as a tool shaping the future of the institution (and the people employed in it). The most important questions which we will try to answer include: To whom and what do these practices give the floor? On what problems do they shed light? Are they a self-diagnostic tool, and if so, to what extent? How do they deal with the subject of the future? The first part is devoted to the phenomenon of institutional critique. It examines its specific nature and development in the activities of Polish directors and curators. In the second part, we show the most salient examples of the Polish "self-diagnostic" theatre. In part three, we are deliberating on the four problematic areas in which theatre institutions are to operate (hierarchisation, precarity of working conditions, capitalist model of "production," and illusions that support the status quo) and the possible scenarios indicated by the theatre performances and curator practices described in the article.

Keywords: institutional critique, Polish theatre, auto-theatre, organisational mechanisms, transformations

Słowa kluczowe: krytyka instytucjonalna, polski teatr, auto-teatr, mechanizmy funkcjonowania instytucji, przemiany 
Wstęp

Jak Wam się wydaje? Czy teatr ma coś jeszcze ważnego do powiedzenia? Że ktoś jeszcze stucha tego, co pada ze sceny?

Lee Breuer

Powyższy cytat to jedna spośród wielu wypowiedzi artystów i artystek tworzących nowojorską scenę awangardową lat 70. i 80 . XX wieku, które zostały wykorzystane w spektaklu/instalacji Kantor Downtown - projekcie zrealizowanym w 2015 roku w Teatrze Polskim w Bydgoszczy przez Jolantę Janiczak, Joannę Krakowską, Magdę Mosiewicz i Wiktora Rubina. Rozpoczynamy nasz tekst nawiązaniem do tego spektaklu, ponieważ łączy on w sobie kilka najważniejszych tendencji obecnych we współczesnych polskich praktykach teatralnych - kluczowych dla rozwijania naszej refleksji. Przedmiotem artykułu jest zjawisko spektakli, a także praktyk kuratorskich, których głównym tematem jest wymiar organizacyjny/produkcyjny/ administracyjny teatru, zarezerwowany dla pracowników instytucji teatralnej czy ekspertów posiadających specjalistyczną wiedzę, a tym samym zwykle niedostępny dla szerokiej publiczności.

Wybrane przez nas praktyki potraktujemy jako narzędzie kształtujące przyszłość instytucji (oraz związanych $\mathrm{z}$ nimi ludzi). W końcu jedną z dominujących motywacji, leżących u podstaw wszelkiej krytyki, jest wiara w umiejętność wywierania wpływu przynoszącego zmianę rzeczywistości. Jak wskazuje Foucault [1997], podstawowym zadaniem krytyki jest wytworzenie sytuacji, w której podmiot, działający w ramach nowocześnie wykształconych instytucji (władzy), stara się odzyskać prawo do decydowania o swoim losie, do decydowania „o sposobie bycia zarządzanym”. Chcemy zastanowić się, jaką rolę odgrywa współczesny krytyczny namysł artystów i kuratorów nad sposobami i logiką działania instytucji, który potocznie jest kojarzony przecież z domeną menedżerów i urzędników. Najistotniejsze pytania, na które będziemy poszukiwać odpowiedzi, są następujące: Komu i czemu praktyki te udzielają głosu? Na jakie problemy zwracają uwagę? Czy - a jeśli tak, to w jakim zakresie - stanowią narzędzie autodiagnostyczne i w jaki sposób podejmują temat przyszłości? W pierwszej części przyjrzymy się zjawisku krytyki instytucjonalnej oraz prześledzimy jej specyfikę i rozwój w działalności polskich reżyserów i kuratorów. W drugiej wskażemy najważniejsze przykłady polskiego teatru „autodiagnostycznego". W trzeciej natomiast zastanowimy się nad czterema problematycznymi obszarami funkcjonowania instytucji teatralnych (hierarchiczność, prekarność warunków pracy, kapitalistyczny model „produkcji”, iluzje wspierające utrzymywanie status quo) oraz możliwymi scenariuszami, na które wskazują opisywane w artykule spektakle i praktyki kuratorskie. 


\section{Co to jest krytyka instytucjonalna i dlaczego podejmuje ją polski teatr?}

„Krytyka instytucjonalna” jako krytyczna praktyka w obrębie sztuki jest kojarzona przede wszystkim z działaniami artystów sztuk wizualnych. Jej cel jest definiowany jako demaskowanie i podważanie mechanizmów działania instytucji sztuki. Początkowe przejawy takiej aktywności - kwestionowanie roli systemu galeryjnego i muzeów w ustanawianiu „reguł gry” (rozumianych za Pierre’em Bourdieu [2005]) - zaczęły krystalizować się na Zachodzie Europy i w USA na przełomie lat 60. i 70. [Raunig, Ray 2009: 13-17] i uzyskały miano I fali krytyki instytucjonalnej. II fala - lata 80. i 90. - to głównie problematyka makroprzekształceń współczesnego życia, takich jak np. rozwój kapitalizmu i jego wpływ na działania instytucji. Ostatnie kilkanaście lat - opisywanych przez teoretyków jako III fala krytyki instytucjonalnej - spaja w sobie dokonania poprzednich jako połączenie krytyki społecznej, krytyki instytucjonalnej i autokrytyki. Specyfika ostatniej fali wydaje się szczególnie istotna w kontekście przeprowadzanej w niniejszym artykule analizy: już nie tylko artyści, ale również świadomi kryzysu kuratorzy zaczęli wcielać do swojej działalności krytyczny imperatyw. Wdrażają transgresyjne praktyki, integrując odmienne rodzaje wiedzy i narzędzia pracy [zob. Möntmann 2009]. Warto zauważyć, że specyfika polskiej krytyki instytucjonalnej różni się od zachodniej ze względu na odmienne doświadczenia ustrojowe, inny rozwój rynku i gospodarki czy społecznych ról instytucji sztuki oraz artysty [Sikora 2015: 179]. Podobnie jak różni się w pozostałych państwach tzw. bloku sowieckiego, przez dziesiątki lat będących pod wpływem doktryny realnego socjalizmu. W związku z tym o polskiej krytyce instytucjonalnej w kategoriach porównywalnych do „zachodnich” można mówić dopiero od momentu, w którym rzeczywistość społeczno-gospodarcza zaczęła przypominać tę zachodnią w zakresie dotyczącym: demokracji, wolnego rynku, wolności słowa, swobody wypowiedzi artystycznej [ibidem: 8].

Powyższy opis odnosi się przede wszystkim do przemian w sztukach wizualnych. W obrębie sztuki teatralnej sytuacja będzie kształtować się w nieco odmienny sposób. Wpływy światowego ruchu kontrkulturowego (który stanowił jeden z fundamentów umożliwiających rozwój krytyki instytucjonalnej) były widoczne w działalności teatrów studenckich lat 70. XX wieku. Pozostawały w kontrze do oficjalnej narracji na temat rzeczywistości i podważały monopol teatrów instytucjonalnych. Wśród nich za najciekawsze można uznać Akademię Ruchu z Warszawy, Teatr Ósmego Dnia z Poznania czy Teatr STU z Krakowa, a także inspirujące się pracami tej pierwszej teatry lat 90.: Strefa Ciszy i Komuna Otwock [Keil 2014]. W strategiach artystów wizualnych „zachodnia” krytyka instytucjonalna wyraziście pojawia się w pierwszym dziesięcioleciu XXI wieku, długo po pojawieniu się tzw. sztuki krytycznej. $\mathrm{W}$ polskim teatrze moment ten przypada na narodziny teatru krytycznego, podejmującego tematykę emancypacyjną, tożsamościową, społeczną (na czele z jego twórcami, takimi jak Monika Strzępka i Paweł Demirski czy Jan Klata). Jak jednak 
zauważa Marta Keil, teatr krytyczny poniósł klęskę, ponieważ nie tylko nie dokonał społecznej zmiany, ale przede wszystkim nie udało mu się zrewolucjonizować zasad produkcji w obrębie własnych instytucji [Keil 2017a]. Oczywiście wynika to nie tylko $\mathrm{z}$ wewnętrznych uwarunkowań teatru, ale także z ram organizacyjnych nałożonych na instytucje przez państwo i samorządy. Być może dziś krytyka instytucjonalna jest próbą przepracowania problemów, z którymi nie poradził sobie teatr krytyczny.

W tym miejscu należy doprecyzować - z perspektywy nauk o zarządzaniu definicję instytucji teatralnych, którym będziemy poświęcać uwagę w niniejszym tekście. Instytucje te rozumiemy w ujęciu przedmiotowym [Glinka, Kostera 2012: 15], jako różnorodne sformalizowane systemy organizacyjne działające w obszarze sztuk performatywnych (repertuarowe teatry publiczne, teatry i festiwale prowadzone przez organizacje pozarządowe oraz teatry komercyjne - prywatne przedsiębiorstwa). Szczególną uwagę będziemy chciały poświęcić także roli interakcji - zarówno tych wewnętrznych, jak i tych związanych z otoczeniem instytucji (na poziomie mikroi makrootoczenia). W kontekście funkcjonowania instytucji teatru interesujące będą dla nas działania odtwarzające i zarazem wytwarzające obowiązujące w polu sztuki performatywne „reguły gry”, o których pisze Ana Vujanović [2015]. Jak wskazuje Marta Keil: „W przestrzeni praktyk teatralnych i choreograficznych proces regulowania instytucji odbywa się w trakcie wytwarzania sytuacji spektaklu, negocjowanej między wytwórcami (performerzy, producenci sztuki) oraz między twórcami i publicznością" [Keil 2017b]. Sztuki performatywne są wysoce zautonomizowane, co przejawia się m.in. $\mathrm{w}$ „nieprzepuszczalności” i niepodatności na zewnętrzne interferencje $w$ wymiarze strukturalnym. Spójrzmy na praktycznie niezmienną od wieków (oczywiście z wyjątkami) hierarchiczność: mechanizmów produkcji spektakli teatralnych (zmieniają się estetyki i konwencje, ale nie zasada pracy oparta na relacjach władzy), sposobów zaangażowania odbiorców (układ: publiczność-scena) oraz weryfikacji wytworów artystycznych (tu: formuły spektaklu). Te trzy reguły w dużym uogólnieniu stanowią najważniejsze przedmioty krytyki instytucjonalnej. Jeżeli na przyjęte tutaj przedmiotowe rozumienie instytucji nałożymy socjologiczny filtr, możemy uznać (odwołując się do Douglassa C. Northa [1990]), że krytyka ta polemizuje zarówno $\mathrm{z}$ instytucjami rozumianymi jako formalne organizacje (prawo, samorząd, państwo), jak i jako nieformalne praktyki (wzorce postępowania przyjęte w samym teatrze). Krytyka instytucjonalna w teatrze nie dotyczy zatem tylko teatru wyizolowanego - jako odrębnej jednostki posiadającej wsobne reguły - ale także poświęca uwagę temu, w jaki sposób reguły te są osadzone i funkcjonują w innych systemach, w ramach których zorganizowane jest nasze życie społeczno-kulturowe.

Joanna Krakowska, podobnie jak Keil, zwraca uwagę na wyczerpanie się języka teatru krytycznego i wyróżnia trzy strategie oddziaływania na sferę publiczną, realizowane/projektowane przez najnowszy polski teatr: 1) ideę nowego teatru publicznego przedstawioną w manifeście Macieja Nowaka „My, czyli nowy teatr publiczny” - skupiającą się wokół idei budowy sojuszu z publicznością, dostępności 
i kształtowania wspólnoty w różnorodności; 2) propozycję Pawła Wodzińskiego i Bartka Frąckowiaka wprowadzania do debaty publicznej (w ramach teatru instytucjonalnego) nowych, niezagospodarowanych jeszcze tematów (a także - to już nasza uwaga - realizowania w jego ramach szerokiej gamy projektów badawczych); 3) auto-teatr - „teatr, którego twórcy mówią ze sceny we własnym imieniu i pod nazwiskiem własnym, a nie scenicznej postaci. Od siebie i o sobie. Odnoszą się do własnych doświadczeń (...), odsłaniają słabości (...), zdradzają kulisy procesu teatralnego (...)" [Krakowska 2016]. Co ciekawe, wszystkie powyższe strategie charakteryzuje autokrytyka i zdolność do autorefleksji, a co za tym idzie, chęć, aby zintegrować sferę deklaratywną z praktyką organizacyjną. Wiążą się one również z III falą krytyki instytucjonalnej, łączącą w sobie refleksję nad: mechanizmami działania instytucji wraz z projektowaniem ich nowych modeli, relacją z widzem oraz rolą sztuki w społeczeństwie. Pokazuje to, że pomimo „niskiej przepuszczalności” reguł obowiązujących w przestrzeni sztuk performatywnych, teatr nie działa w próżni: żywo reaguje na rzeczywistość społeczną, kulturową i polityczną oraz wypracowuje nowe, mające na nią wpływać, narzędzia. Jak sugerujemy w naszej argumentacji, jednym z nich może być właśnie wyeksponowanie sfery organizacyjnej. Chodzi o to, by stała się kwestią publiczną i - parafrazując Brunona Latoura [2010: 113-116] - by wprowadzić ją z powrotem w „oświetlone miejsce”, na scenę, która stanowi jedną z najważniejszych przestrzeni komunikacji zarówno z szeroko rozumianą publicznością, jak i z różnorodnymi podmiotami działającymi wewnątrz pola. W końcu podstawowym „produktem” teatralnej działalności artystycznej jest „spektakl” i to wokół niego koncentrują się i mobilizują wszelkie wysiłki.

\section{Polski teatr „autodiaģnostyczny” i jego syntetyczna mapa}

W związku z tak rozumianym statusem „spektaklu” w teatralnej rzeczywistości chciałybyśmy spojrzeć na krytykę instytucjonalną właśnie przez jego pryzmat. Dlatego w poniższej części zarysujemy syntetyczną mapę polskich spektakli i działań kuratorskich - nazwanych przez nas „teatrem autodiagnostycznym” - które wpisują się w scharakteryzowaną w poprzedniej części III falę krytyki instytucjonalnej. W polskim teatrze „autodiagnostyczny boom” rozpoczął się w 2015 roku. Ważnym punktem odniesienia dla polskiego środowiska artystów i kuratorów sztuk performatywnych (a być może i inspiracją) były z pewnością przypadające na 2015 rok obchody 250-lecia teatru publicznego, zorganizowane z inicjatywy Instytutu Teatralnego im. Zbigniewa Raszewskiego w Warszawie. Podczas całorocznych obchodów znaczący dla środowiska teatralnego teoretycy oraz praktycy debatowali na temat kondycji polskiego teatru publicznego, próbując uchwycić jego specyfikę i zdiagnozować doskwierające mu problemy. Swoją premierę miały w tamtym czasie takie spektakle, jak komentujący relacje władzy i struktury pracy w sztuce Kantor 
Downtown (realizacja Jolanta Janiczak, Joanna Krakowska, Magda Mosiewicz i Wiktor Rubin), a także odnoszący się do sytuacji zawodowej aktorów spektakl Aktorzy $\dot{z} y d o w s c y$ (reż. Anna Smolar), eksponujący specyfikę pracy techników teatralnych spektakl Kwestia techniki (reż. Michał Buszewicz) czy opowieść o mechanizmach pracy w teatrze i profesji aktora Ewelina płacze (reż. Anna Karasińska). Także 2016 rok obfitował w projekty takie, jak testujący relację scena-widz Drugi spektakl (reż. Anna Karasińska), Triatlon (reż. Adam Nalepa, Anna Wieczur-Bluszcz, Igor Gorzkowski) o procesie pracy artystycznej, Take it or make it (koncepcja Ana Vujanović) o możliwości demokratycznej, grupowej pracy twórczej, a także projekty kuratorskie i prezentowane w ich ramach prace, wśród których nie można pominąć zainicjowanego przez Tomasza Platę cyklu „Mikroteatr” Komuny//Warszawa. Na uwagę - ze względu na podjęcie "gry” z mechanizmami działania festiwalu - zasługują także Konfrontacje Teatralne kuratorowane przez Martę Keil i Grzegorza Reske (i ich 21. edycja: „Autonomia/Instytucja/Demokracja”). Rok 2017 to kolejny projekt Platy „Makroteatr”: cztery 16-godzinne spektakle reklamowane hasłem: ,jeszcze jeden test, czy da się robić teatr tak, / jak się go zazwyczaj nie robi / sprawdzian, co zostanie z teatru / bez początku, środka i końca" [Komuna//Warszawa, strona internetowa]. I oczywiście Klątwa Olivera Frljića wystawiona w Teatrze Powszechnym w Warszawie, zwracająca uwagę na tematy takie, jak np. prekarność pracy aktorów czy odpowiedzialność reżysera, ale przede wszystkim testująca granice sztuki i cenzury - tego, ile w dzisiejszej Polsce można powiedzieć i pokazać na scenie teatralnej. W roku 2018 spektaklem 2118 Anna Karasińska zainaugurowała kolejny projekt Platy - „Teatr 2118” - dotyczący teatralnej i pozateatralnej przyszłości. W jego ramach zostały również zapowiedziane projekty Wojtka Ziemilskiego i Ani Nowak. $\mathrm{Na}$ koniec warto wspomnieć również o East European Performing Arts Platform, realizowanym już w latach 2012-2013 cyklu Re/mix, Komunie//Warszawa i dyrekcji (2014-2017) Pawła Wodzińskiego i Bartka Frąckowiaka w Teatrze Polskim w Bydgoszczy. Działania te będziemy szerzej komentować w następnych częściach artykułu.

\section{Dysfunkcje, zalecenia i (nie)prawdopodobne scenariusze}

Na podstawie argumentacji przedstawionej w pierwszej i drugiej części przyjmujemy założenie, że analizowane przez nas praktyki (spektakle i projekty kuratorskie podejmujące tematykę funkcjonowania instytucji teatralnych) wpisują się w nurt III fali krytyki instytucjonalnej oraz stanowią narzędzie autodiagnostyczne. Zdają się zwracać uwagę na problemy świata teatralnego i wyeksponować je, czyniąc $\mathrm{z}$ nich przedmiot debaty publicznej. W związku z powyższym wyróżniłyśmy pięć kategorii - dysfunkcji, które zostały „naświetlone” przez współczesny polski teatr. Naszym celem nie będzie jednak ich pogłębiona analiza (wymagałoby to pracy wykraczającej daleko poza objętość niniejszego artykułu), ale ich uporządkowanie 
wraz z lapidarnym zarysowaniem kontekstu. Musimy w tym miejscu podkreślić, że sugerowane przez nas poszczególne kategorie nie są $\mathrm{w}$ żadnym wypadku rozłączne: funkcjonują w złożonej sieci wzajemnych zależności, osadzonej w szerszym społeczno-ekonomiczno-kulturowym kontekście. Przyjrzyjmy się im bliżej.

\subsection{Znasz slowo hierarchia?' - nadużcia wladzy, patriarchat i folwark}

Twórcy spektaklu Kantor Downtown o dysfunkcjach współczesnych relacji władzy $\mathrm{w}$ teatrze opowiadają przez pryzmat postaci Tadeusza Kantora. Z pozoru niewinne, przywoływane w Kantor Downtown „ustawianie” aktorów przez kanonicznego twórcę polskiego teatru, przejawiające się np. w „tupaniu, strofowaniu i pokrzykiwaniu”, uruchamia pytanie o status aktora całkowicie zależnego od woli i humorów reżysera. Padające w spektaklu słowa Kantora: „Moi aktorzy pracują cały dzień i noc" prowokują z kolei do namysłu nad statusem aktora jako pracownika. Te dwa aspekty zostają następnie „zmiksowane” w wypowiedzi jednej z artystek - Penny Arcade. Jak mówi, Kantor i inni „tacy jak on” są „,autorami przez duże A” - wybitnymi jednostkami, odznaczającymi się unikalnym talentem i zasługami dla kanonu teatralnej awangardy. W polskiej tradycji wciąż aktualny jest mit romantycznego artysty, którego nie obowiązują żadne reguły. To takiemu reżyserowi pozwala się na instrumentalne traktowanie aktorów w imię wyższego celu, jakim jest realizacja "genialnego spektaklu”.

Jak wskazuje Grzegorz Niziołek [2010]: „W tej chwili cała władza spoczywa w rękach wybitnych reżyserów (...), którzy zdradzają dość konserwatywny stosunek do form instytucjonalnych: liczy się uległość wobec egoistycznego żądania reżysera-władcy". W powszechnym obiegu nie zwraca się uwagi na fakt, że takie rozumienie zadań reżysera to pokłosie dopiero przełomu XIX i XX wieku i Wielkiej Reformy Teatru (a mogłoby to przecież znacząco dowartościować subwersywne praktyki w obrębie ustanawiania procesu pracy artystycznej). Zresztą dyskutowany tutaj rodzaj stosunków pojawia się w różnych zawodowych konfiguracjach i można zilustrować go pojęciem "relacji folwarcznych" - służących ustalaniu hierarchii i legitymizacji statusu silniejszego, w warunkach skrajnej nierówności stron [zob. Leder 2017]. W kontekście nadużyć skierowanych przeciwko aktorom - tu aktorkom kobietom warto również przypomnieć słowa Klary Bielawki, które wykrzykuje ze sceny podczas Klątwy Olivera Frljića: „Podobało się? Taka «Klątwa» Wyspiańskiego? Cała gromada na scenie upokarza jedną aktorkę i zmusza ją do odegrania żenującej roli? Tarzam się na scenie, jestem malowana jak krowa, a koledzy się podśmiechują. Performowanie, kurwa, tożsamości. Tylko jakimś trafem to kobieta zawsze ląduje na kolanach (...)”.

${ }^{1}$ Zapisane kursywą tytuły podrozdziałów w trzeciej części artykułu pochodzą ze spektaklu Kantor Downtown. 
Wypowiedź Bielawki podkreśla, w jaki sposób polski teatr reprodukuje patriarchalne i przemocowe relacje władzy oraz ujawnia, że wykorzystywane do tego narzędzia są wysublimowane (właściwe specyficznemu teatralnemu kontekstowi), zakamuflowane i powszechnie stosowane. Z kolei w spektaklu Kwestia techniki w reżyserii Michała Buszewicza pracownicy techniczni - „aktorzy” (Jarosław Majzel, Janusz Rojek i Mirosław Wiśniewski) - opowiadają nie tylko o sobie i swojej pracy - często pomijanej i deprecjonowanej - ale także o hierarchii w obrębie samego zespołu teatralnego, która przejawia się m.in. w „systemie gwiazdorskim”. Folwarczność nie kończy się oczywiście na stosowaniu np. przemocy symbolicznej, ale realizuje się także w wymiarze ekonomicznym, o którym piszemy w następnym punkcie.

\subsection{Mają kredyty, dzieci, rachunki i w promieniu $100 \mathrm{~km}$ nie ma innego teatru - prekarnośc warunków pracy aktorow}

Aktorka Marta Malikowska wchodzi na widownię i prosi widzów o ujawnienie i wypisanie na jej ciele czarnym grubym flamastrem wysokości ich zarobków. Najpierw zdradza własne. Część z widzów spełnia jej prośbę, kilkoro z pozostałych chichocze. To znów fragment wielokrotnie przywoływanego wcześniej spektaklu Kantor Downtown. W Mikro-Dziadach Anny Smolar (realizowanych w Komunie// Warszawa w ramach projektu Tomasza Platy „Mikroteatr”) Malikowska, choć wymieniona w obsadzie, w ogóle się nie pojawia. Słyszymy jej głos „z offu”: tłumaczy, że miała lepiej płatny spektakl w innym teatrze. Z kolei w debiucie Anny Karasińskiej Ewelina płacze Maria Maj, Adam Woronowicz i Rafał Maćkowiak grają stażystów, którzy grają Maj, Woronowicza i Maćkowiaka. Aktorzy - jak w mikrospektaklu Smolar - grają w tym samym czasie w solidniej wynagradzanych produkcjach. W Klątwie Barbara Wysocka pyta o popremierowe, socjalne konsekwencje pracy aktora: „Problem będzie, jak mi zamkną zakład pracy i wypierdolą dyrektora na zbity ryj. Czy wtedy Oliver Frljić zapłaci za przedszkole, szkołę i żarcie dla trójki moich dzieci?". W ten sposób twórcy demaskują mit napędzający system produkcji teatralnej. Zgodnie z nim zanegowanie motywacji ekonomicznej umożliwia uzyskanie dystynktywnego społecznego statusu [zob. Jacyno 1997] - artysty aktora grającego w prestiżowym teatrze. Okazuje się jednak, że taka „obietnica” nie wystarczy do tego, aby przetrwać w realiach późnego kapitalizmu. Związane jest to oczywiście z przekształceniami w obrębie samej struktury instytucji, o których piszemy w następnym akapicie. 


\subsection{Teatralne fabryki - produkcja, projekt, tempo, efekt}

Komuna//Warszawa, 16-minutowe Mikro-Dziady: po niespełna sześciu minutach referowania wszystkich części Dziadów Mickiewicza Jan Sobolewski wygłasza monolog wychwalający wszelkie ograniczenia w tworzeniu sztuki, w tym malejące budżety. W jego wypowiedzi wybrzmiewają jedne z największych lęków dzisiejszego środowiska artystycznego: 1) cenzura ekonomiczna - praktykowana dziś przez obecnego Ministra Kultury i Dziedzictwa Narodowego, np. w stosunku do Festiwalu Malta czy Teatru Polskiego w Bydgoszczy, oraz 2) komercjalizacja sztuki - jak dotąd blokowana przez system teatrów publicznych (mimo ich problematycznego statusu, np. ignorowania potrzeby wsparcia eksperymentalnych projektów, które już dziś funkcjonują w sferze przymusowego „mikroteatru”). Wpływ modelu kapitalistycznego jest widoczny na szczeblu rudymentarnych mechanizmów pracy w sztuce. Koncentracja na szybkim i efektywnym wytwarzaniu prac artystycznych jest domeną najważniejszych polskich ośrodków teatralnych. Przymus nieustannej produktywności upodobnił te instytucje do fabryk podążających za logiką produkcji, mimo że paradoksalnie późny kapitalizm (przejawiający się przede wszystkim w ekspansywnym rozwoju przemysłów kreatywnych [zob. Reckwitz 2017]) dowartościował cechy zazwyczaj kojarzone z pracą artystów: kreatywność, mobilność i rozwój. East European Performing Arts Platform (EEPAP) to przykład instytucji, która idzie w poprzek „fabrycznym” imperatywom: ważniejszy jest tu sam proces twórczy, edukacja, działalność badawcza i wymiana środowiskowa. Oczywiście model działalności EEPAP nie jest uniwersalny. Zwraca on jednak uwagę na problem systemu teatralnego w Polsce - dominację modelu instytucjonalnego teatru repertuarowego, działającego wedle dwóch niezmiennych reguł: intensywnego, projektowego procesu produkcji i fetyszyzacji efektu, czyli spektaklu gotowego do wielokrotnej prezentacji [zob. Niziołek 2010]. Również projekty realizowane przez Tomasza Platę w Komunie//Warszawa odsłaniają dyskutowane tutaj instytucjonalne mechanizmy produkcji, a także przypominają, że efekt artystyczny zawsze zależy od warunków organizacyjnych, w których powstaje.

\subsection{La magiczuą kurtyną - iluzje teatralnegoo świata}

Pierwsza scena spektaklu Kwestia techniki: na scenie, w rytm elektronicznej muzyki, „tańczą" czarne zastawki. Przesuwają się jak w sztuczce z kostką i kubkami - przywodzą na myśl skojarzenia z pokazem iluzjonistycznym. Elementy konstrukcyjne, które zazwyczaj w teatralnej konwencji są „przezroczyste”, skupiają na sobie całą uwagę publiczności. Chwilę później na scenę wchodzą inni „niezauważalni” - technicy teatralni, reprezentujący zaledwie wycinek całej rzeszy niewidzialnych pracowników teatru. „Niewidzialność” ich pracy sprawia, że jest niżej ceniona (przez 
instytucje i ich pracowników, zarówno w rozumieniu statusu - prestiżu, jak i finansów - wynagrodzeń), ukryta za „zasłoną” spektaklu. Oddanie maszynistom - choć na chwilę - miejsca na scenie, poza zwróceniem uwagi na trudne relacje w zespole teatralnym, ujawnia mechanizmy wytwarzające iluzję. Problem „artystycznej zasłony" jako narzędzia do odwracania uwagi od nierozwiązanych instytucjonalnych problemów, pojawia się w metaforyczny sposób także w sztuce Kantor Downtown. Podczas gdy Malikowska wygłasza żądania wobec swojego „pracodawcy”: „(...) chcę, żeby teatr stworzył mi odpowiednie warunki do bycia twórczynią! Jestem autorką!", Grzegorz Artman w roli apodyktycznego reżysera rozkazuje podgłośnić muzykę. Z każdym kolejnym zdaniem Malikowskiej reżyser powtarza nieznoszące sprzeciwu komendy: „Głośniej! Głośniej!”. Ten fragment ilustruje także to, na co zwracała uwagę w Klątwie Klara Bielawka: metody „zagłuszania sztuką” w teatrze są powszechnie przyjęte i aprobowane. Inną perspektywę dotyczącą iluzoryczności teatralnych praktyk obierają natomiast autorzy, składającego się z pięciu taneczno-teatralnych solo, spektaklu Take it or make it. Twórcy za cel obrali sobie wypracowanie jak najbardziej demokratycznego procesu twórczego i sprawdzenie, do jakiego stopnia jest on możliwy do przeprowadzenia. Problem polega na tym, że żaden z performerów nie może do końca zrealizować swojego planu, ponieważ jak się okazuje - brakuje osoby, która mogłaby tym procesem pokierować. W tym miejscu zdają się pobrzmiewać echa jednego z głównych dysonansów polskiego teatru, o którym pisała Szczawińska [2017]: „Teoria wie swoje i produkuje utopijne scenariusze - tymczasem praktyczna instytucja działa zupełnie inaczej". Problemem jest fakt, na który trafnie zwraca uwagę Niziołek [2010]: „(...) samo środowisko teatralne strzeże tego status quo [dlatego, że] [d]aje ono poczucie bezpieczeństwa. Najbardziej wpływowi reżyserzy, którzy mogliby doprowadzić do przebudowy systemu teatralnego w Polsce, w momencie kiedy stają się wpływowi, przestają być tym zainteresowani - bo to oni rozdają od tego momentu karty (...)”. Jaką przyszłość teatru widzą autorzy przywoływanych przez nas praktyk?

\section{5. (Nie)prawdopodobne scenariusze}

W spektaklu Kwestia techniki maszyniści - w konwencji czarnego humoru - snują wizję tego, co może się wydarzyć, jeśli nic nie zmieni się w obrębie relacji pomiędzy pracownikami teatru: ciche zbrodnie na aktorach, „podkładanie nóg” i inne niejawne złośliwości, których celem jest wywrócenie panującego „nieporządku”. Publiczność się śmieje, maszyniści rechoczą. Aby lepiej zrozumieć tę scenę, sięgnijmy do Zygmunta Baumana: na skutek zdewaluowania idei postępu i rosnącej frustracji wynikającej z niemożliwości przewidywania i kształtowania swojego losu przy pomocy dostępnych narzędzi, „(...) przyszłość z naturalnej ostoi nadziei i prawowitych oczekiwań zmienia się w przestrzeń koszmaru - w przestrzeń wypełnioną lękami” [Bauman 
2018: 15]. To każe nam domniemać, że narzędzia, jakimi są czarny humor czy „żarty branżowe" (pojawiające się w większości z wymienionych przez nas spektakli), pomagają oswoić lęki. Jak wskazują Monika Kostera i Martyna Śliwa [2010: 224-225], to właśnie ironia i humor są jedną z podstawowych form organizacyjnego oporu, ponieważ pozwalają na podważanie istniejących systemów władzy, bez sięgania po otwartą konfrontację. W dzisiejszych przestrzeniach pracy jest to często jedyna możliwa forma sprzeciwu [Contu 2008, za: Kostera, Śliwa 2010: 225].

Oczywiście nie wszystkie wizje, które wyłaniają się z opisywanych tutaj spektakli i praktyk, są równie pesymistyczne. Inny scenariusz na „przyszłość teatru” zaproponował Tomasz Plata. Kurator sugeruje, że interesującym odniesieniem dla teatru są współczesne formaty narracyjne: 18-minutowe wystąpienia specjalistów na TED-zie oraz „taśmowe” oglądanie seriali: „Konwencja youtubowa z jednej strony i konwencja netflixowa $\mathrm{z}$ drugiej to dwa nowe rodzaje odbioru dzieł, które kształtują współczesnego widza, a instytucjonalny teatr z nimi nie gra” [Szymańska 2017]. Powyższe przesłanki stały się jedną z inspiracji do stworzenia cyklów „Mikroteatr” i „Makroteatr”. Wyjątkową ideę na polskiej mapie teatralnej proponuje zresztą cała Komuna//Warszawa, budowana jako alternatywna instytucja kultury. Eksploruje nowe wzorce produkcji teatralnej, wspiera działania eksperymentalne, łączy odmienne środowiska twórcze („Re/mix”, „Mikroteatr”, „Makroteatr”), ustanawia nawet nowe kanony dzieł artystycznych („Re/mix”).

Jak dotąd pojawiły się dwa wyraziste pomysły na „nowe” teatralne instytucje. Paweł Wodziński i Bartek Frąckowiak, dyrektorzy Teatru Polskiego w Bydgoszczy, zaproponowali model teatru komentującego rzeczywistość nie tylko przy pomocy działań artystycznych (spektakli), ale również w oparciu o rozbudowany program badawczy (wykłady, seminaria, konferencje, a także warsztaty i panele dyskusyjne) - zwykle nadal sprzężony z działaniami artystycznymi, jednak traktowany jako równie istotny. Choć propozycję tę realizowali w ramach instytucjonalnego teatru repertuarowego i można spierać się o jej efekty, wskazuje ona na potrzebę różnicowania form organizacyjnych instytucji teatralnych i celów ich działalności. Druga koncepcja to inspirowany francuskim théâtre populaire projekt publicznego teatru popularnego Macieja Nowaka. Oprócz widowiskowej estetyki, Nowak wskazywał na potrzebę budowania sojuszu z publicznością [Nowak 2016]. Gdy Roger Planchon, francuski reżyser, definiował teatr popularny, mówił, że chce robić teatr, który będzie się podobał jego niepiśmiennej matce i intelektualiście z Paryża [Czapliński et al. 2016]. Niektóre z opisywanych przez nas spektakli, np. Kwestia techniki czy Drugi spektakl, wydają się skłaniać ku takiemu rozumieniu teatru popularnego. Narzędzia, którymi operują, to właśnie zwrot w stronę odbiorcy (zauważanie widza i - niekiedy - próba wejścia z nim w dialog) oraz posługiwanie się dowcipem.

Ostatni scenariusz, wyłaniający się w zasadzie z każdego omawianego przez nas spektaklu czy praktyki kuratorskiej, to całkowita zmiana coraz trudniejszych do zaakceptowania produkcyjnych „reguł gry”. Aby uporać się z takimi problemami, 
jak folwarczne relacje w zespole teatralnym czy bezmyślne reprodukowanie kapitalistycznego modelu wytwarzania, prezentowania i sprzedawania „produktu” - spektaklu, potrzebne są m.in. nowe modele produkcji: nie tylko zreformowane publiczne teatry repertuarowe, ale także domy produkcyjne, sceny impresaryjne, regularnie dotowane teatry prowadzone przez organizacje pozarządowe czy instytuty badawcze i ośrodki eksperymentalne. Dopiero w takich warunkach pracownicy teatru uzyskaliby przestrzeń do kształtowania nowych idei, nowych relacji i poddawania refleksji celów działalności twórczej.

\section{Podsumowanie i powrót do przyszlości}

Wydaje się, że rosnące wśród teatralnych twórców zainteresowanie „autodiagnostycznymi” formami działalności jest przejawem wykształcania się nowego modelu instytucjonalnej samoświadomości. Jednak kiedy przyjrzymy się zakresowi poruszanych tematów, okaże się, że nie jest on wyczerpujący. Całkowicie pomijane jest chociażby zagadnienie zespołu administracyjnego. Nie „mówi się” także o znaczących dysproporcjach w wynagrodzeniach między dyrektorami teatrów i topowymi reżyserami a pozostałymi pracownikami. Ta przesłanka sugeruje, że polski teatr „autodiagnostyczny” będzie się rozwijał i dostarczał nowej wiedzy. Kwestią sporną pozostaje jednak to, na ile jego głos będzie brany pod uwagę w kształtowaniu przyszłości instytucji teatralnych, a także czy uda się zintegrować sferę deklaratywną z praktyką instytucjonalną.

Warto postawić pytanie, czy analizowane przez nas praktyki tylko wytwarzają sytuację spektaklu „o krytyce”, czy też rzeczywiście wdrażają krytyczne postulaty na różnych poziomach swojej działalności. Problematycznym przykładem może być tutaj Frljić. Choć podczas przedstawienia daje aktorom przestrzeń na wyrażanie swojej niezgody i frustracji dotyczącej warunków pracy, nie decyduje się na faktyczną zmianę „reguł gry” tam, gdzie - nawet w mikroświecie spektaklu - mógłby je zmienić. W Klątwie Wysocka mówi: „Odważny twórca. Przyjeżdża na miesiąc, robi spektakl (...), po czym spierdala do Monachium albo innego Mariboru robić za tysiące eurasków kolejny. (...) On nie jest żadnym twórcą antysystemowym, tylko pierdolonym hipokrytą i tchórzem". Czy na pewno wygłoszenie wątpliwości ze sceny sprawia, że problem zostaje rozwiązany? Bojana Kunst wskazuje, że instytucje zatracają dziś swój emancypacyjny potencjał, mogą proponować krytyczny program artystyczny, jednak na poziomie organizacyjnym powielać kapitalistyczne metody działania [Kunst 2016]. Pozostanie wyłącznie teatralnym „nurtem” byłoby dla teatru „autodiagnostycznego" fiaskiem.

$\mathrm{Z}$ drugiej strony, jeśli weźmiemy pod uwagę dyskurs jako jedną z najważniejszych przestrzeni, w których rozgrywa się obecnie walka o władzę, prognozy mogą być nieco bardziej optymistyczne. Oczywiście musimy zastanowić się, dlaczego mocny „w słowach” 
teatr krytyczny okazał się nieskuteczny, podobnie jak działania takie, jak np. „Teatr nie jest produktem / widz nie jest klientem" z 2012 roku czy niedawny (kwiecień 2018) strajk „niewidzialnych pracowników” Opery Narodowej. Jeśli ziści się pozytywny scenariusz i czekają nas przemiany na poziomie instytucjonalnym, powinniśmy przygotować się na naprawdę długą drogę. Siła takich działań nie polega na gwałtownych transformacjach, ale na dysolucyjnym rozpuszczaniu systemu: wprowadzaniu doń nowych kategorii, tożsamości, reguł, które powoli, ale jednak, zmieniają zasady gry.

\section{Bibliografia}

Bauman Z. (2018), Retrotopia: Jak rządzi nami przeszłość, tłum. K. Lebek, Warszawa: Wydawnictwo Naukowe PWN.

Bourdieu P. (2015), Reguły sztuki: Geneza i struktura pola literackiego, tłum. A. Zawadzki, Kraków: Universitas.

Czapliński J. et al. (2016), Wokót teatru popularnego, „Dialog”, nr 9, [dok. elektr.], dostęp online: http://www.e-teatr.pl/pl/artykuly/248080.html [odczyt: 20 lipca 2018].

Foucault M. (1997), The Politics of Truth, ed. S. Lotringer, L. Hochroch, New York: Semiotext(e).

Glinka B., Kostera M. (red.) (2012), Nowe kierunki w organizacji i zarzadzaniu: organizacje, konteksty, procesy zarządzania, Warszawa: Oficyna Wolters Kluwer business.

Jacyno M. (1997), Iluzje codzienności: O teorii socjologicznej Pierre’a Bourdieu, Warszawa: Wydawnictwo IFiS PAN.

Keil M. (2014), Remiksy w Komunie Warszawa (2010-2013), [dok. elektr.], dostęp online: http:// www.e-teatr.pl/pl/artykuly/179876,druk.html [odczyt: 14 lipca 2018].

Keil M. (2017a), Kto was tu wpuścił, teatralne prowokatorki?, [dok. elektr.], dostęp online: http:// www.zorkawollny.net/OFELIE/index.php/pl/marta-keil-kto-was-tu-wpuscil-teatralne-prowokatorki/ [odczyt: 20 lipca 2018].

Keil M. (2017b), Do kogo należy teatr? O tym, do czego może nam się dzisiaj przydać krytyka instytucjonalna, „Dialog”, nr 11(732), [dok. elektr.], dostęp online: http://www.dialog-pismo. $\mathrm{pl} / \mathrm{w}$-numerach/do-kogo-nalezy-teatr-o-tym-do-czego-moze-nam-sie-dzisiaj-przydac-krytyka-instytucjonalna [odczyt: 5 lipca 2018].

Komuna//Warszawa, strona internetowa, dostęp online: http://komuna.warszawa.pl/event/ makroteatr/ [odczyt: 14 lipca 2018].

Kostera M., Śliwa M. (2010), Zarządzanie w XXI wieku: jakość, twórczość, kultura. Podręcznik akademicki, Warszawa: Wydawnictwa Akademickie i Profesjonalne.

Krakowska J. (2016), Auto-teatr w czasach post-prawdy, [dok. elektr.], dostęp online: http:// www.dwutygodnik.com/artykul/6756-auto-teatr-w-czasach-post-prawdy.html [odczyt: 5 lipca 2018].

Kunst B. (2016), Artysta w pracy: O pokrewieństwach sztuki i kapitalizmu, Warszawa-Lublin: Instytut Teatralny im. Zbigniewa Raszewskiego - Konfrontacje Teatralne Centrum Kultury w Lublinie. 
Latour B. (2010), Splatając na nowo to, co społeczne. Wprowadzenie do teorii aktora-sieci, tłum. A. Derra, K. Abriszewski, Kraków: Universitas.

Leder A. (2017), Relacja folwarczna, „Krytyka Polityczna”, nr 45, [dok. elektr.], dostęp online: http://krytykapolityczna.pl/kraj/leder-relacja-folwarczna/ [odczyt: 9 lipca 2018].

Möntmann N. (2009), The Rise and Fall of New Institutionalism: Perspectives on a Possible Future, [w:] Raunig G., Ray G. (ed.), Art and Contemporary Critical Practice: Reinventing Institutional Critique, London: MayFly Books.

Niziołek G. (2010), Dwa tysiąclecia prawie i ani jednego boga!, „Didaskalia”, nr 99, [dok. elektr.], dostęp online: http://www.didaskalia.pl/99_niziolek.htm [odczyt: 15 lipca 2018].

North D. C. (1990), Institutions, Institutional Change, and Economic Performance, Cambridge: Cambridge University Press.

Nowak M. (2016), My, czyli nowy teatr publiczny, „Dialog”, nr 6, [dok. elektr.], dostęp online: http://dialog-pismo.pl/w-numerach/my-czyli-nowy-teatr-publiczny [odczyt: 17 lipca 2018].

Raunig G., Ray G. (2009), Preface, [w:] eidem (ed.), Art and Contemporary Critical Practice: Reinventing Institutional Critique, London: MayFly Books.

Reckwitz A. (2017), Odkrycie kreatywności: O procesie społecznej estetyzacji, tłum. K. Kończal, Z. Sucharska, Warszawa: Narodowe Centrum Kultury.

Sikora P. (2015), Krytyka instytucjonalna w Polsce w latach 2000-2010, Wrocław: BWA Wrocław-Galerie Sztuki Współczesnej.

Szczawińska W. (2015), Teoretyczne demokracje, praktyczne instytucje, „Polish Theatre Journal”, nr 1, [dok. elektr.], dostęp online: http://www.polishtheatrejournal.com/index.php/ptj/ article/view/121/602 [odczyt: 21 lipca 2018].

Szymańska I. (2017), Tomasz Plata, kurator projektu „Makroteatr”, opowiada, jak YouTube i Netflix zmieniaja teatr, [dok. elektr.], dostęp online: http://www.e-teatr.pl/pl/artykuly/248080. html [odczyt: 24 lipca 2018].

Vujanović A. (2015), The Magic of the Artworld (Three Scenes from Belgrade), „Performance Research", vol. 20, no. 4, 30-38. 